\title{
張家口地下水調查
}

多田交男・西村嘉助・泉實，

(資源科學研究所)

\section{Ground water of Kalgan}

By Funio Tada, Kasuke Nisimura and Minoru Izomi

\section{1. 序 言}

垏者等は昭和 14 年夏と昭和 15 年夏との二包に亘つて張家口市街の井戶

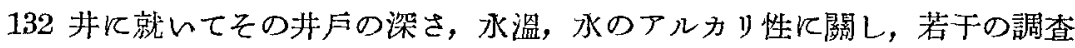
一老行つた。即ち，昭和 14 年 8 月 2 日 3 日に清水河の河東地域の 36 井に 就いて，同月 10 日，11日飞河西地域の 18 井に就いて調べた。

更に昭和 15 年 9 月 9 日, 10 日, 11 日, 12 日の 四日間に亘つて河西， 河東の井今 78 井䍭びに地表水に就いて測定を行つた。その概要をと〉に報 告する事とした。本調查汶東亞研究所の費用を以て行つをるのであり，現地 の軍站びに興亞院蒙㢾聯絡部の御援助を受けた。此處に感謝を表する次第で ある。

\section{2. 張家口盈地の地形”, “地質}

張家口盆地はその北・東・西の三方を山地に圍をれを盆地であつて，南側が 開けて羊河の沖積华野に連つてるる。此の盆地の北側は西西北から東東南に

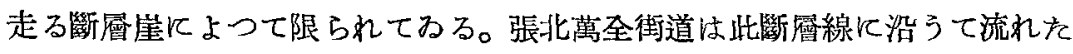
谷に沿うて居るのである。清水河は大境門外飞於て南天門方面から流れて來 を支流を合せて南流し，乙の㫁層崖を切つて盆地に入り，張家口を河東と河 西の二地域に分つて居る。河東地域て於て汶，此断層崖下に大をな犀狀地が 發達して居る。此河東地域の扇狀地の上層 20 〜 $30 \mathrm{~m}$ 江砂碟を混じた黄土層 より成り，その下部に第三紀の赤色粘土乙碟層の互層がある。地下水は黃 土中には存せす，その下層に溜つて居る。河西地域に於ては賜鬼山麓に扇狀 地が發達してるるが，その發達は河東地域程著るしくない。その代り山地と 


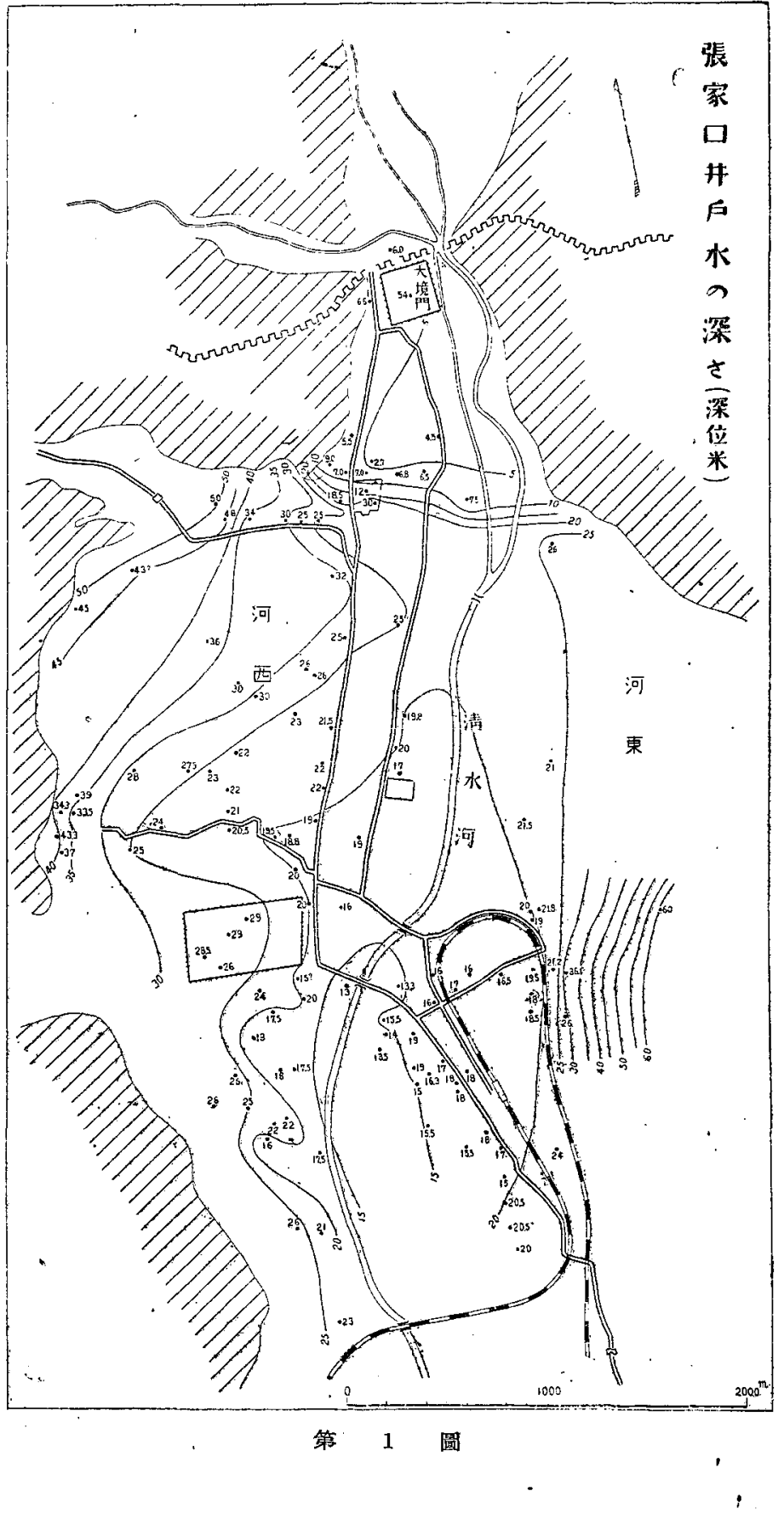


盆地之の境に低い丘棱地が發達してるる。此邱稜地は薄い黄土或は磷混りの 二次的黃土によつて蔽沈れてるるがその基盤牥赫色粘土である。

大境門から察南政廳に至る清水河の谷注古い張蒙口層の山地を切つを狭い 沖積平野であつて，5〜10 m 位の深さで基盤に達するものの如くである。此 地域を張家口北部地域之名付けて置く。

\section{3. 井戸の深さ一}

第一圖には井戶の口から水面迄の深さを記入してある。井户の水面は四季 によつて多少の差があるへく， 爻一日の中でも水を汲み出してるる特之，そ の前後に於いて差があるものと考へられるが，水深が 1〜3mであるから差 は夫程大をくない模樣である。

$\alpha_{1}$ 河東地域

井戶の染さ汁河東地區に於ては清水河の近くに於いて最も淺く $12 〜 16 \mathrm{~m}$ であり東の方山地に近づくに從つて深くなつてるる。領事館の井戸は $60 \mathrm{~m}$ にも達してるる。地下水位法次項に記す如く，河邊でも東の山麓でも著るし い差がないのであるから，東侧で井戶の梁くなるのは黃土や砅より成る扇狀 地が發達して居て地表面が東に行くに從つて高くなる爲である。

$\alpha_{2}$ 河西地域

河西地域でも清水河に沿うれ所で井戶の深さが淺く 13〜20 m であるが， 西側の賜覀山麓に近つくに從つて深くなり，平門の邊りで注 $50 \mathrm{~m}$ を越して わる。之も地下水面は略同じなのであるが，山麓に庼狀地が發達して居て， 地表面の高度が高くなつてるる鹞である。新民大街に沿うて井户の泚い地帶 を認める事が出來るが，その理由は明かでない。或は第二の地下水瀑布があ る胥ではないかと考へられる。

$\alpha_{3} \quad$ 北部地域の地下水瀑布

察南政廳之與亞院第三宿舍を連好る線を境として，その北部に於ては井户

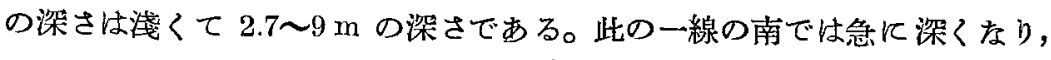
僅か 2 300 $\mathrm{m}$ の水平距離の所で $30 \mathrm{~m}$ 亿達してるる。此の邊りは一帶に清 水河の沖積地であつて，地表面の高さの差は殆どない。地下水の水位が北側 
で高く，南側で低く，此處に地下水瀑布が作られてるる爲に井戸の深さにも

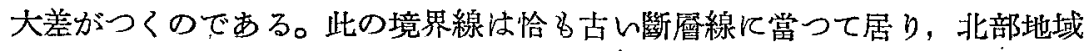
がーつの段丘を形成してるる事が知られるのである。

\section{4. 黃土層と帶水層}

張家口各地に於けるボーリングの結果を見ると帶水層は黄士層とは無闢係

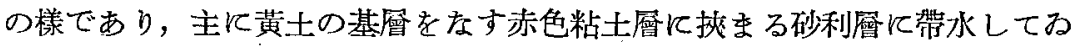
る樣である。張家口の河東地域は北東側山地からの庼狀地上にある。此の㞛 狀地の地質は表面が砂利混りの黃士から出來てねるがその厚い所でも $20 \mathrm{~m}$ であり，その下笪は赤色の粘士，砂及び砅から成つて居る。而して地下水の 深さ汢薪狀地で注 $19 \mathrm{~m}$ の深さのもの一井を見るのみであつて，他は總べて $21 \mathrm{~m}$ 以上であつてた。黄土中には地下水を發見する事心出來をんのである。

\section{5. 地下水の温庋}

昭和 14 年夏井戶水の溫度を測定しを結果では水溫は略っ一定であつて, $10.5^{\circ} \mathrm{C}$ 附近であつた。詳細見ると深い井户で水溫が幾分高い样である。

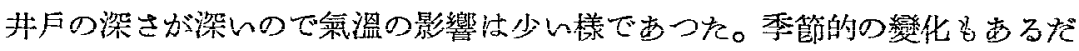
らうが測定してない。

\section{6. 地下水の $\mathrm{R} \mathrm{pH}$}

地下水のアルカリ度を知る爲に離合会製の $\mathrm{pH}$ 此色計を用ひて井戸水の $\mathrm{pH}$ 及 $\mathrm{R} \mathrm{pH}$ 值を測定した。第 2 圖に将昭和 14 年度の夏に测定した $\mathrm{pH}$ の值を本字で示し，昭和 15 年の夏に测定した值を下線付で記してある。 一般飞昭和 14 年の測定值のアルカリ度が高く出てるる。之は地下水の $\mathrm{pH}$ が變化した爲ではなくして測定の誤差である。昭和 15 年に用ひた比色計は 昭和 14 年に用ひたものと同型のものではあるが，昭和 14 年に購入しれ篇 飞色が裉をたのではないかと考へられる。同じ井户の水を測定した結果兩年 度の差汢次表の如くである。

昭和 14 年 昭和 15 年

察南政廳・西の井戶 $\mathrm{RpH}$ 


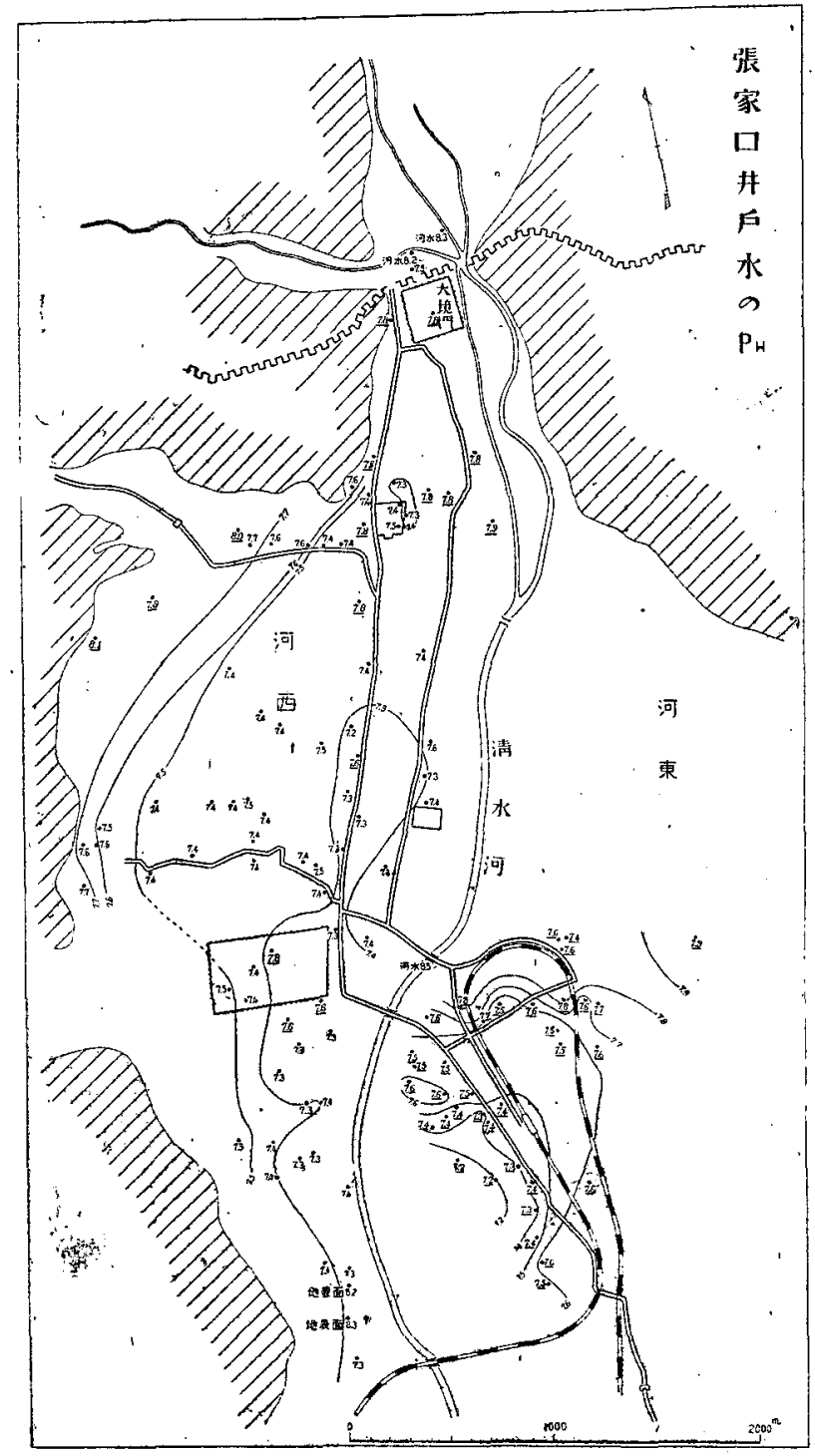

第 2 圆

昭和 15 年度の測定值は 0.4 低く出て居る。綮密な訂正を行ふ迄取敢へず測 定值をその儘記入して置いた。

河東地域 昭和 14 年の測定值に依孔ぱ河東地域に於て山清水河に近い所 
で一般に $\mathrm{pH}$ が低く $7.3 〜 7.5$ の值を示してるるが東側に行つて扇狀地の下 の水の $\mathrm{pH}$ 度壮高くなつて領事館の井戶水は 7.9 亿達してみる。井戸の深 さの大きいものはアルカリ度が高く淺いものが低くなつてるる樣に思へる。 之之深し所へ行く之 $\mathrm{pH}$ の值が高くなると言ふ事になる。又地下水の水面高 度から見ると水面の高いものが $\mathrm{pH}$ の值が低く，低いものが高い樣にも思

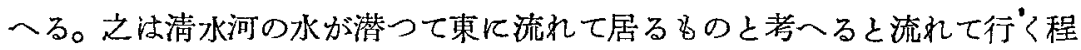
pH が高くなると言ふ事となる。

河西地域 昭和 15 年の測定值に依れ泣河西地域に於ては清水河に近几所 で一般にアルカリ性が弱く，7.3〜 7.4 と云ふ $\mathrm{RpH}$ の檤を示してねるが西 に行つて賜鬼山麓に至ると7.6〜 7.7 と言ふ高い值を示して居る。此處でも 深い井户の水がアルカリ度の高い事を示してるる。

北部地域 昭和 14 年度の 測定值によると $7.5 \sim 7.9$ の值であつて他の地 域の水に比して著るしくアルカリ性が强い。昭和 15 年度の測定值に依つて も7.3〜7.6であつて他の地域の水よりるアルカリ性が强い。此の地域の井 户の深さは著るしく淺く一般に $10 \mathrm{~m}$ 以下である。

表面水 昭和 15 年清水河の水をすをして，その上澄みの水の $\mathrm{RpH}$ を測 定しそ所によれば大境門外の本流にて 8.3 同じく南天門側支流に於て 8.2 漢 鄉橋畔にて 8.5 と云ふ高レアルカリ性を示して居る。又河西地域南部の窑廠 に於いて屿地下水の $\mathrm{pH}$ は 7.3〜7.4 であるが，之を地表に没み上げ溜池に 湛へて置いたものでは 8.2〜8.3 と云ふ高い值を示してみる。因に賜鬼山の 泉の水怊和 15 年飞 7.3 であり水母宫の泉水は昭和 14 年度に 7.6 であ つそ。岩の割目から出る水の pH は一般に低い栐である。

結 び $\mathrm{RpH}$ の值は地表の水に於いて最も高く 8.2〜8.5を示し, 北部地 域の淺い井戸でも相當に高く $7.6 \sim 7.8$ を示して居る。恰も地表の $\mathrm{pH}$ の高 い水が浸透して少しくアルカリ性を失つれかの趣がある。河東・河西兩地域 の深い井Fの水の $\mathrm{pH}$ の值は著しく低くなる。淸水河の水が地中を潜る間 スアルカリ性を失つたのではないか。併し此處では深い井戶程アルカリ性が 强くなる。 
張家口の地下水

昭和 14 年夏測定の分

\begin{tabular}{|c|c|c|c|c|c|c|c|}
\hline & 處 & & $\begin{array}{l}\text { 水面迄の } \\
\text { 深さ (m) }\end{array}$ & $\begin{array}{l}\text { 水底迄の } \\
\text { 采さ }(\mathrm{m})\end{array}$ & ${ }^{\circ}$ 水 ${ }^{\text {湓 }}$ & $\mathbf{p H}$ & $\mathrm{RpH}$ \\
\hline $\begin{array}{l}\text { 1. 東 } \\
2 . \text { 沙 } \\
\text { 3. 沙 } \\
\text { 5. }\end{array}$ & 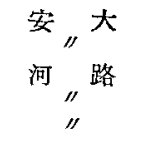 & $\begin{array}{l}\text { 街 } \\
\text { 街 }\end{array}$ & $\begin{array}{l}16.5 \\
19.5 \\
19 \\
20 \\
21.8\end{array}$ & $\begin{array}{l}19.0 \\
21 \\
21 \\
23 \\
23.5\end{array}$ & $\begin{array}{l}10.5 \\
10.5 \\
10.5 \\
10.7 \\
11.0\end{array}$ & $\begin{array}{l}7.2 \\
7.2 \\
7.2 \\
7.1 \\
6.9\end{array}$ & $\begin{array}{l}7.6 \\
7.8 \\
7.6 \\
7.6 \\
7.4\end{array}$ \\
\hline 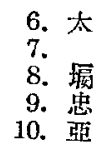 & 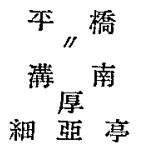 & $\begin{array}{c}\text { 南 } \\
\text { 街 } \\
\text { 黑 } \\
\text { 西 }\end{array}$ & $\begin{array}{l}21.2 \\
36 \\
26 \\
24 \\
18.5\end{array}$ & $\begin{array}{l}23.7 \\
39 \\
36 \\
27 \\
21.5\end{array}$ & $\begin{array}{l}10.5 \\
10.5 \\
10.5 \\
10.7 \\
10.5\end{array}$ & $\begin{array}{l}7.0 \\
7.3 \\
1.9 \\
7.2 \\
7.1\end{array}$ & $\begin{array}{l}7.6 \\
7.7 \\
7.6 \\
7.6 \\
7.5\end{array}$ \\
\hline $\begin{array}{l}\text { 11. 鐵 } \\
\text { 12. 東 } \\
\text { 13. 長 } \\
\text { 14. } \\
\text { 15. 寶 }\end{array}$ & 安路 & $\begin{array}{l}\text { 街 } \\
\text { 街 } \\
\text { 街 }\end{array}$ & $\begin{array}{l}18 \\
18 \\
18 \\
18 \\
18\end{array}$ & $\begin{array}{l}21 \\
21 \\
21 \\
26 \\
21\end{array}$ & $\begin{array}{l}10.5 \\
10.5 \\
10.5 \\
10.5 \\
10.5\end{array}$ & $\begin{array}{l}7.1 \\
6.8 \\
6.8 \\
6.9 \\
6.8\end{array}$ & $\begin{array}{r}7.5 \\
7.4 \\
. \quad 7.3 \\
7.4 \\
7.3\end{array}$ \\
\hline $\begin{array}{l}\text { 16. 保 } \\
\text { 17. 王 } \\
\text { 18. 夲 } \\
\text { 19. 泰 } \\
\text { 20. 七 }\end{array}$ & 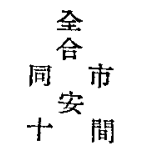 & $\begin{array}{l}\text { 街 } \\
\text { 黑 } \\
\text { 昜 } \\
\text { 盟 } \\
\text { 房 }\end{array}$ & $\begin{array}{l}17 \\
15.5 \\
15.5 \\
15 \\
20.5\end{array}$ & $\begin{array}{l}21 \\
23 \\
23 \\
22 \\
23.5\end{array}$ & $\begin{array}{l}10.5 \\
10.5 \\
10.5 \\
10.5 \\
10.5\end{array}$ & $\begin{array}{l}6.9 \\
6.8 \\
6.8 \\
6.8 \\
7.0\end{array}$ & $\begin{array}{l}7.4 \\
7.2 \\
7.2 \\
7.3 \\
7.4\end{array}$ \\
\hline $\begin{array}{l}21 . \\
22 . \\
23 . \\
24 . \\
.25 . \\
.4 \text { 花 }\end{array}$ & $\begin{array}{l}\text { "I } \\
\text { " } \\
\text { 園 } \\
\text { 壽 }\end{array}$ & $\begin{array}{l}\text { 園 } \\
\text { 街 } \\
\text { 街 }\end{array}$ & $\begin{array}{l}20.5 \\
20 \\
13.5 \\
14 \\
16.3\end{array}$ & $\begin{array}{l}23.5 \\
23 \\
21.5 \\
23 \\
23.3\end{array}$ & $\begin{array}{l}10.5 \\
10.5 \\
10 \cdot 5 \\
10.5 \\
10.5\end{array}$ & $\begin{array}{l}7.2 \\
7.1 \\
7.0 \\
6.9 \\
6.9\end{array}$ & $\begin{array}{l}7.6 \\
7.5 \\
7.6 \\
7.5 \\
7.4\end{array}$ \\
\hline $\begin{array}{l}26 . \text { 福 } \\
27 \text {. 㮐 } \\
28 . \text { 高 } \\
29 . \text { 言 } \\
30 \text { 北 }\end{array}$ & $\begin{array}{l}\text { 譸 潢 } \\
\text { 園 } \\
\text { 安 } \\
\text { 馬 } \\
\text { 市 }\end{array}$ & $\begin{array}{l}\text { 街 } \\
\text { 巷 } \\
\text { 熏 } \\
\text { 路 } \\
\text { 場 }\end{array}$ & $\begin{array}{l}19 \\
15 \\
22.5 \\
16 \\
16\end{array}$ & $\begin{array}{l}25 \\
23 \\
25.5 \\
19.8 \\
22.5\end{array}$ & $\begin{array}{r}11.2 \\
10.5 \\
10.5 \\
10.5 \\
9.6\end{array}$ & $\begin{array}{l}7.0 \\
7.0 \\
7.0 \\
7.0 \\
7.2\end{array}$ & $\begin{array}{l}7.6 \\
7.4 \\
7.4 \\
7.5 \\
7.6\end{array}$ \\
\hline 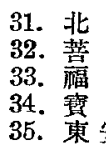 & 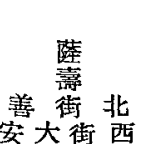 & $\begin{array}{l}\text { 繁 } \\
\text { 街 } \\
\text { 街 } \\
\text { 口 } \\
\text { 櫋 }\end{array}$ & $\begin{array}{l}13.3 \\
15.5 \\
16 \\
17 \\
17\end{array}$ & $\begin{array}{l}19.3 \\
21.5 \\
21.4 \\
21 \\
28\end{array}$ & $\begin{array}{r}10.5 \\
9.5 \\
10.5 \\
10.5 \\
10.1\end{array}$ & $\begin{array}{l}7.2 \\
7.2 \\
7.0 \\
6.9 \\
70\end{array}$ & $\begin{array}{l}7.6 \\
7.5 \\
7.5 \\
7.5 \\
7.7\end{array}$ \\
\hline $\begin{array}{l}\text { 36. 停 } \\
37 . \text { 驛 } \\
38 . \\
\text { 39. 領 }\end{array}$ & $\begin{array}{c}\text { 車 } \\
\text { 前 } \\
\text { 新廣 } \\
\text { 倳 }\end{array}$ & $\begin{array}{l}\text { 場 } \\
\text { 場 } \\
\text { 館 }\end{array}$ & 60 &.- & 11.0 & 7.2 & 7.9 \\
\hline $\begin{array}{l}\text { 43. 繁 } \\
\text { 44. 花 } \\
\text { 45. 大 }\end{array}$ & 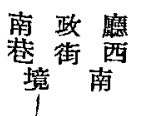 & $\begin{array}{l}\text { 西 } \\
\text { 口 } \\
\text { 阿 }\end{array}$ & $\begin{array}{r}18.5 \\
4.0 \\
3.4\end{array}$ & $\begin{array}{l}1.9 \\
5.5 \\
6.6\end{array}$ & $\begin{array}{l}10.3 \\
10.3 \\
10.4\end{array}$ & $\begin{array}{l}7.2 \\
7.2 \\
7.4\end{array}$ & $\begin{array}{l}7.8 \\
7.8 \\
7.8\end{array}$ \\
\hline
\end{tabular}




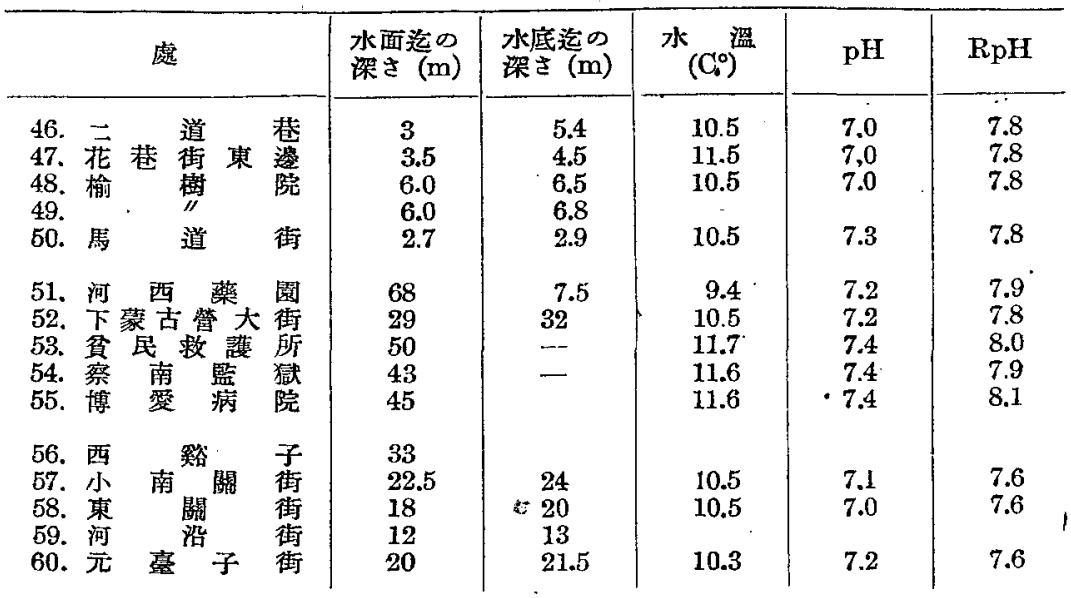

昭和 15 年夏測定の分

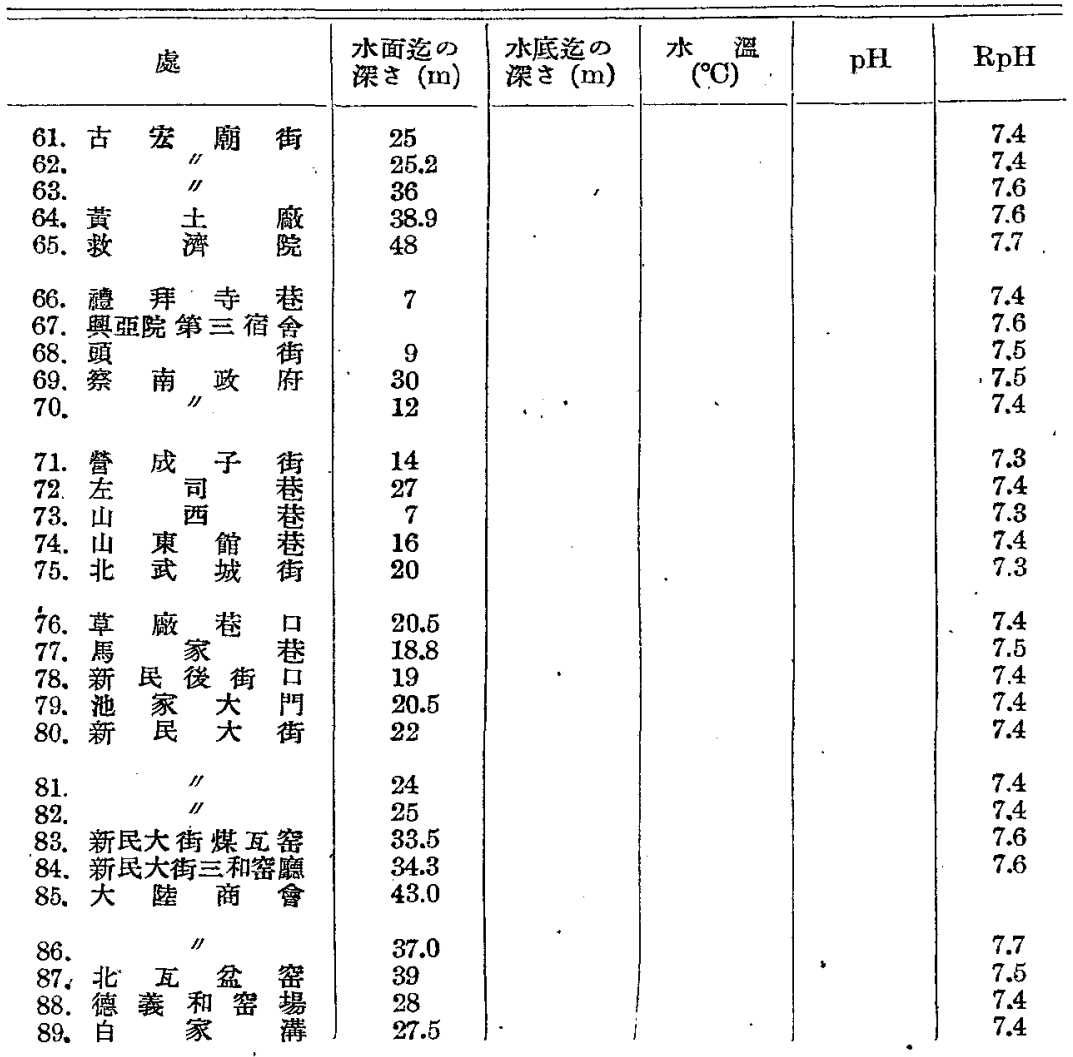




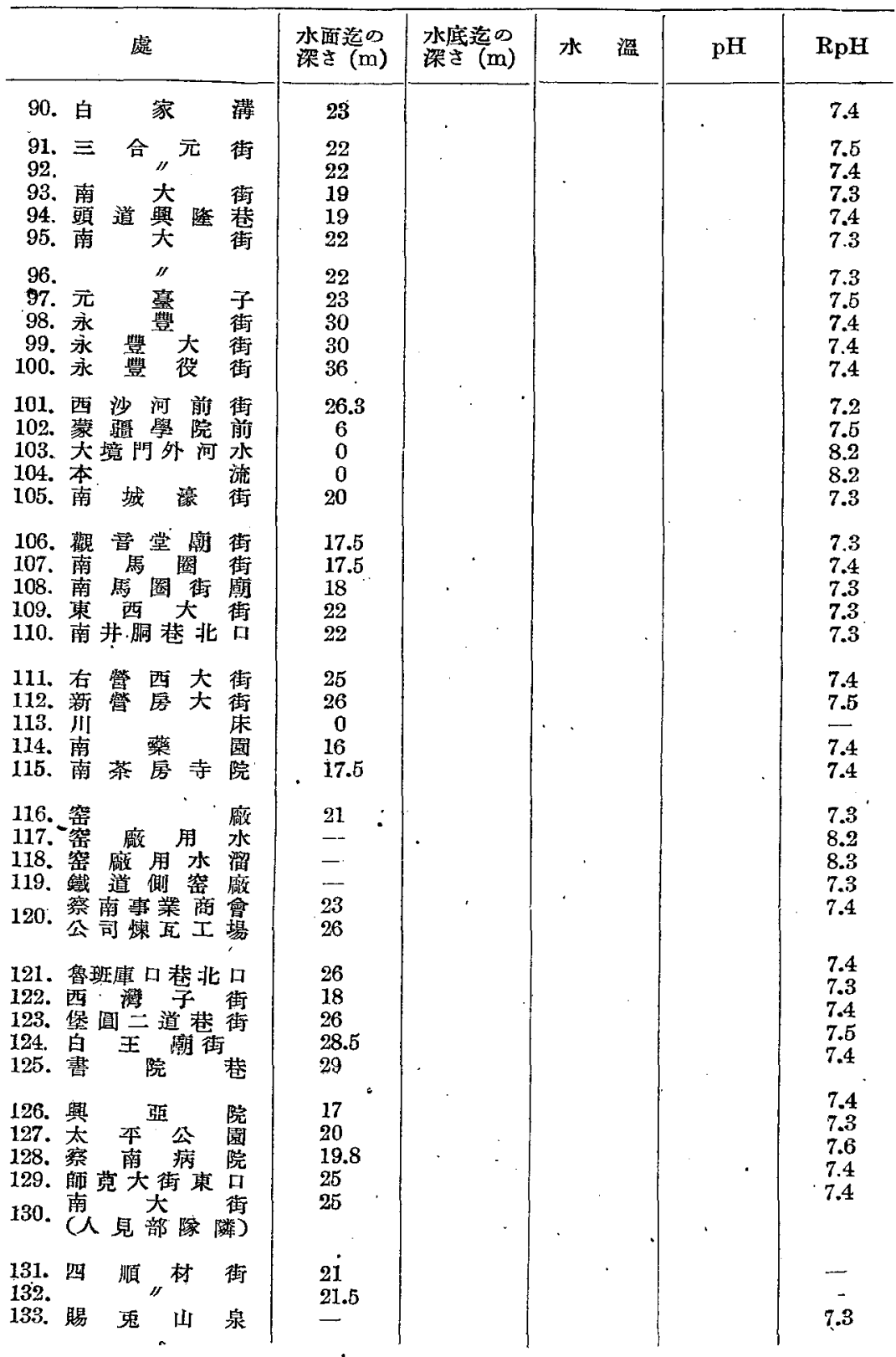

黄土の中に水大れて盢くとアルカリ性が强くなるものの如くである。因 みに黄土の $\mathrm{pH}$ の值は 8〜8.5 である。 